\title{
Sistema eólico úmido nas sucessões sedimentares interderrames da Formação Mosquito, Jurássico da Província Parnaíba, Brasil
}

\author{
Aeolian wet system in the sedimentary intertraps successions of \\ Mosquito Formation, Jurassic of the Parnaiba Province, Brazil \\ Oscar Arturo Romero Ballén ${ }^{1 *}$, Ana Maria Góes², Francisco de Assis Negri³ \\ Mariana Velcic Maziviero ${ }^{4}$, Vinicius Zacatei do Santos Teixeira ${ }^{5}$
}

RESUMO: Relativo à tectônica dos eventos precursores da gênese do Oceano Atlântico central, na Província Parnaíba ocorre a Formação Mosquito, uma sucessão de derrames basálticos com intercalaçôes de camadas sedimentares. Estes depósitos acumularam-se sobre paleobaixos topográficos e seus contatos são erosivos na base e no topo das sucessōes sedimentares. No vale do rio Mosquito encontra-se a mais espessa sucessão sedimentar: o Membro Macapá. Este consiste em uma sucessáo de arenitos com as associaçōes de fácies de campos de dunas eólicas com depósitos de interduna encharcada, lençóis de areia com fluviais efêmeros e playa siliciclástica. Os pacotes de sucessóes sedimentares interderrames isolados e de pouca continuidade são interpretadas como associaçôes de 1) margem de playa lake; 2) lençóis de areia; e 3) campos de dunas eólicas. O nível relativo do lençol freático foi o fator que mais influenciou a sedimentaçấo das unidades interderrames, controlando a disponibilidade sedimentar e a superfície de acumulação. A variação do nível freático foi resultante das variaçóes climáticas e, provavelmente, das condiçôes da taxa de subsidência.

PALAVRAS-CHAVE: rochas sedimentares interderrames; análise de fácies; estratigrafia de sistemas desérticos.
ABSTRACT: Prior to the tectonic events related to the opening of the Central Atlantic, the Mosquito Formation of Jurassic age in the Parnaiba Sedimentary Basin was deposited as a succession of interbedded basaltic flows and sedimentary packets. The sedimentary successions deposits accumulated in topographic depressions with erosional contacts at both their base and top. Their contacts with the basalts are marked by eolian supersurfaces. The thickest intertrapp unit in the formation, the Macapa Member, found in the Mosquito river valley, is made up of sandstones comprising three facies associations: 1) eolian dune fields with interdune pond deposits, 2) sand sheets with ephemeral fluvial deposits and 3) siliciclastic sabkha. Relative water level, which controlled sediment availability and the accumulation surface and varied as a function of climate and probably subsidence rate, was the most important factor affecting intertrapp sedimentation in the Mosquito Formation.

KEYWORDS: sedimentar intertraps; facies analysis; deserts system stratigraphy.

\footnotetext{
${ }^{1}$ Programa de Pós-Graduação em Geoquímica e Geotectônica, Instituto de Geociências, Universidade de São Paulo - USP, São Paulo (SP), Brasil. E-mail: oscaromerob@gmail.com

${ }^{2}$ Instituto de Geociências, Universidade de São Paulo - USP, São Paulo (SP), Brasil. E-mail: goes@igc.usp.br

${ }^{3}$ Instituto Geológico, Secretaria do Meio Ambiente do Estado de São Paulo, São Paulo (SP), Brasil. E-mail: negri@igeologico.sp.gov.br

${ }^{4}$ Programa de Pós-Graduação em Geociências, Instituto de Geociências, Universidade Estadual de Campinas - Unicamp, Campinas (SP), Brasil. E-mail: mariana. maziviero@ige.unicamp.br

5Instituto de Geociências, Universidade de São Paulo - USP São Paulo (SP), Brasil. E-mail: vini.zacatei@gmail.com

*Autor correspondente

Manuscrito ID 29979. Recebido em: 28/05/2013. Aprovado em: 05/12/2013.
} 


\section{INTRODUÇÃO}

Episódios magmáticos precursores à gênese do oceano Atlântico são amplamente conhecidos nas bacias intracratônicas brasileiras e africanas, e dada a sua importância para a compreensão da geodinâmica da Plataforma Sul-Americana, tem sido assunto de diversos trabalhos e.g. Marzoli et al. (1999), Baksi e Archibald (1997), Thomaz-Filho et al. (2000, 2008). Entre os episódios magmáticos, em parte representados por derrames basálticos gerados pelo rifteamento do Gondwana, têm sido documentadas várias sucessôes sedimentares continentais (e.g. Mountney et al. 1999, Scherer 2002), que auxiliam no entendimento da evolução paleoclimática e ambiental dessas regióes. Na Província Parnaíba (Almeida et al. 1977), Northfleet e Melo (1967) descreveram a presença de camadas sedimentares eólicas intercaladas com derrames de basaltos da Formação Mosquito, objeto de investigação do presente trabalho.

Diversos trabalhos relatam que em sucessóes eólicas a acumulação ocorre em vários breves episódios de sedimentação alternados com períodos de erosão ou não deposição (e.g. Kocurek 1988, Kocurek \& Havholm 1993, Langford \& Chan 1988, Mountney \& Thompson 2002). Na Província Parnaíba, depósitos sedimentares eólicos foram alternados por derrames de basaltos que interromperam a sedimentação eólica, se sobrepondo a ela. Este tipo de relação já foi discutido na literatura para outras bacias (Clemmensen 1988, Mountney et al. 1999, Scherer 2002). O estudo das diferentes associações de fácies e suas superfícies limitantes auxilia na determinação das acumulações eólicas geneticamente relacionadas, ou seja, sequências eólicas (Kocurek 1988, Kocurek \& Havholm 1993, Mountney 2006). No caso da Formação Mosquito foi possível, além de caracterizar os contatos entre os basaltos e as sucessóes sedimentares, distinguir mediante a análise faciológica, mudanças tanto na disponibilidade sedimentar como no clima, entre as diferentes sequências deposicionais. Exemplos de sistemas desérticos úmidos parecidos com o observado são descritos na literatura no Bristol Dry Lake, na California (Handford 2006), onde ocorrem associaçóes de sabkha com campos de pequenas dunas e interdunas úmidas.

Os objetivos principais deste trabalho foram: (1) identificar as relaçóes estratigráficas tanto nos contatos basalto-arenito quanto das diferentes associações de fácies; (2) caracterizar as possíveis sequências sedimentares intercaladas na Formação Mosquito. E assim, discutir um modelamento estratigráfico de acumulação, construção e preservação das sucessôes sedimentares, tendo como base as exposiçóes rochosas situadas no centro da Província Parnaíba (Fig. 1), nas proximidades das cidades de Fortaleza das Nogueiras e Formosa da Serra Negra - MA, utilizando como principal ferramenta a análise faciológica.

\section{MARCO TECTÔNICO E ESTRATIGRÁFICO}

Durante o Paleozoico na Província Parnaíba ocorreu a sedimentação de uma espessa sucessão sedimentar em uma bacia intracratônica tipo sinéclise denominada Bacia do Parnaíba (Góes 1995, Pedreira da Silva et al. 2003). No estágio final de deposição da sinéclise paleozoica, a sequência deposicional do Grupo Balsas, formaçóes Piauí, Pedra de Fogo, Motuca e Sambaíba (Fig. 2A), mostra uma tendência de continentalização dos ambientes deposicionais, enquanto o clima se tornava cada vez mais quente e seco (Lima Filho 1998, Góes 1995, Góes et al. 1993, Mabesoone 1977). Possivelmente no Triássico, após a deposição de campos de dunas e draas da Formação Sambaíba, ocorreu um hiato estratigráfico que é, segundo Vaz et al. (2007), relacionado com a Orogenia Allegeniana.

Na Província Parnaíba estão registrados dois eventos magmáticos principais associados à evolução do processo de ruptura dos continentes sul-americano e africano (Thomaz Filho et al. 2000, 2008), representados pelos magmatismos básico a intermediário, que culminou com a quebra do supercontinente Gondwana.

O magmatismo básico toleítico, com idade jurássica inferior ca. 190 Ma (Fig. 3), na Província Parnaíba, está representado pela Formação Mosquito (Fig. 2B), constituído principalmente por derrames, e mais localmente por soleiras e diques, considerado correlato ao Magmatismo Penatecaua das bacias do Amazonas e Solimóes. Por outro lado, o magmatismo básico, também de natureza toleítica, com idades de ca. $130 \mathrm{Ma}$ (Neocominiano), na Província Parnaíba, está mapeado como Formação Sardinha (Aguiar 1971). Esta ocorre principalmente na forma de diques e soleiras de diabásio (Fig. 1). Estes eventos magmáticos estão relacionados, no caso da Formação Mosquito, ao rifteamento do Atlântico central, enquanto que a Formação Sardinha, mais jovem relacionada ao rifteamento do Atlântico sul (Almeida 1986, Milani \& Thomaz Filho 2000, Veevers 2004).

Dados geoquímicos indicam que as rochas básicas das formaçôes Mosquito e Sardinha são toleíticas, de baixo a alto-Ti e alto-Ti, respectivamente (Fodor et al. 1990, Baksi \& Archibald 1997, Merle et al. 2011), provavelmente do tipo fissural, com os diques e as soleiras encaixados nas unidades sedimentares subjacentes da bacia (Nascimento et al. 2010). Merle et al. (2011) reconhecem um terceiro subgrupo de basalto, relacionado aos basaltos de alto-Ti evoluídos. A pilha vulcânica básica da Formação Mosquito, com espessura máxima de 250 m (Góes et al., 1993), aflora principalmente na porção centro-oeste da Bacia do Parnaíba, na região entre Imperatriz e Porto Franco, a oeste, entre Fortaleza dos Nogueiras e Grajaú, na porção leste. 


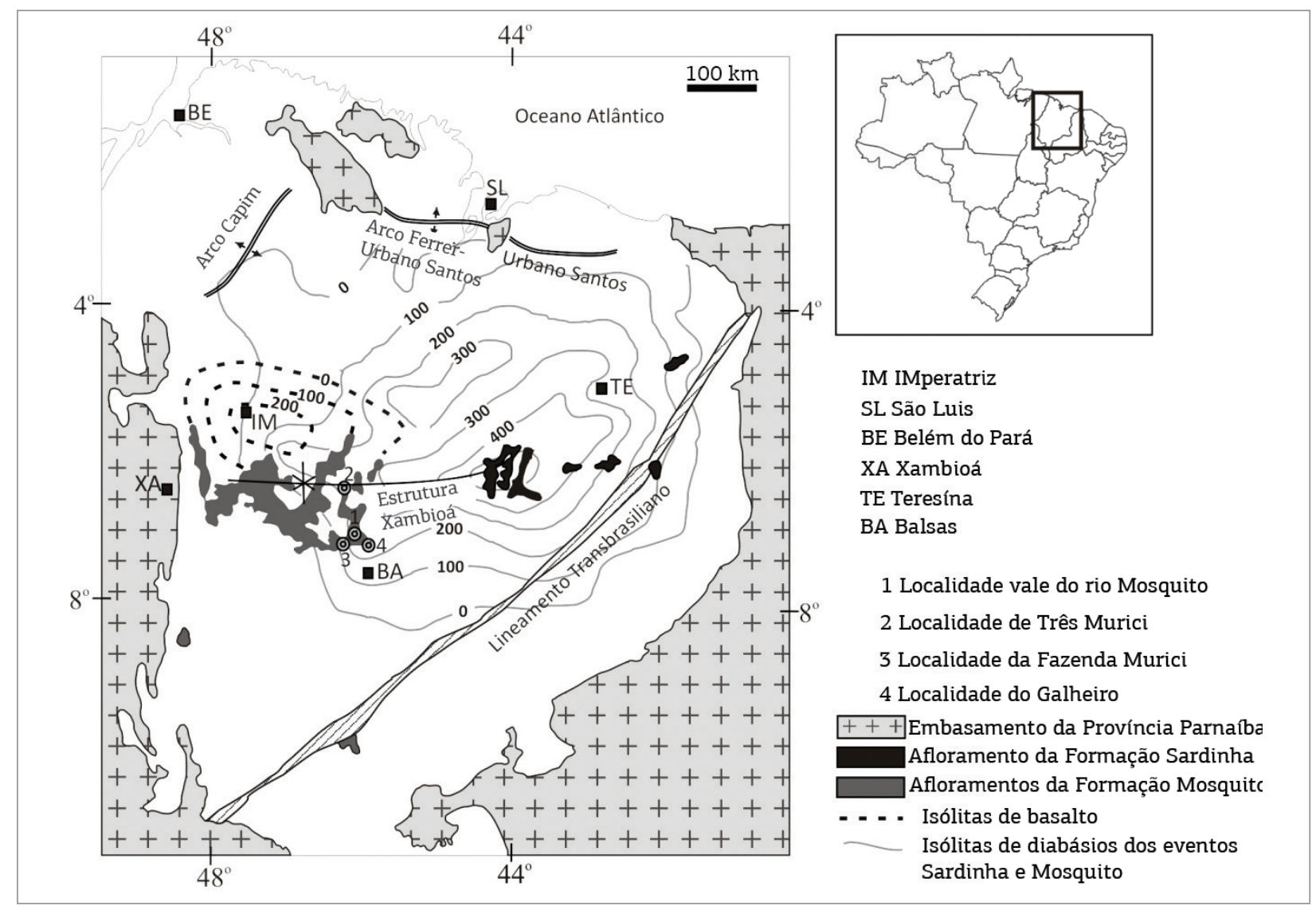

Figura 1. Mapa esquemático mostrando a distribuição da Formação Mosquito e as possíveis feições tectônicas atuantes no Jurássico na Província Parnaíba. Os diques e soleiras das formações Mosquito e Sardinha encontram-se intrudindo principalmente rochas paleozoicas. Estas não são diferenciáveis em subsuperfície. Notar que a Estrutura de Xambioá parece ter exercido controle durante este magmatismo. Modificado de Góes et al. (1993).

Os contatos estratigráficos da Formação Mosquito são discordantes, tanto na base com os arenitos com estratificaçôes cruzadas de até $8 \mathrm{~m}$ de espessura da Formação Sambaíba, quanto no topo com os arenitos arroxeados com estratificaçóes cruzadas de até $2 \mathrm{~m}$ de espessura da Formação Corda (Aguiar 1971, Cunha \& Carneiro 1972, Rezende 2002, Romero 2012).

Dentro da Formação Mosquito no vale do rio Mosquito, Northfleet e Melo (1967) descreveram a presença de intercalaçóes de camadas sedimentares interderrames na unidade. Os autores definiram como Membro Macapá o pacote de arenitos que ocorre na porção inferior da formação, e Membro Tingui, composto predominantemente de siltitos e silexitos posicionados próximo ao topo da formação. Um resumo da estratigrafia da Formação Mosquito na área a sudeste de Fortaleza dos Nogueiras é apresentada na Fig. 2B.

\section{MATERIAIS E MÉTODOS}

Para a interpretação dos ambientes deposicionais, foi seguido o procedimento de análise de fácies segundo Walker (1992) e Miall (2000). As fácies foram determinadas com base nos litotipos com ênfase na granulometria, nas estruturas sedimentares e na geometria das camadas. As associaçôes de fácies foram definidas como agrupamentos de fácies, cujos processos atribuídos são coetâneos e geneticamente relacionados, e por fim foram reconstituídos os processos deposicionais. A análise faciológica foi feita pelo levantamento de seçóes colunares e panorâmicas. Nestas últimas, foram identificadas as fácies, os elementos arquitetônicos e as hierarquias de superfícies limitantes. Além disso, foram realizadas medidas das atitudes das superfícies limitantes e das paleocorrentes. Os dados de paleodireção do vento onde foi observada claramente a estratificação cruzada acanalada foram interpretados usando o método das exposições tridimensionais dos limbos descrito por DeCelles et al. (1983), que consiste em medir os flancos dos estratos cruzados acanalados da duna para encontrar o eixo que representaria a direção do paleovento.

Para auxiliar na identificação das fácies, foram realizados estudos petrográficos de 10 amostras dos arenitos interderrames. Para tanto, foi feita avaliaçáo modal dos componentes e texturas deposicionais e diagenéticas, com contagem de 300 pontos por amostra. 


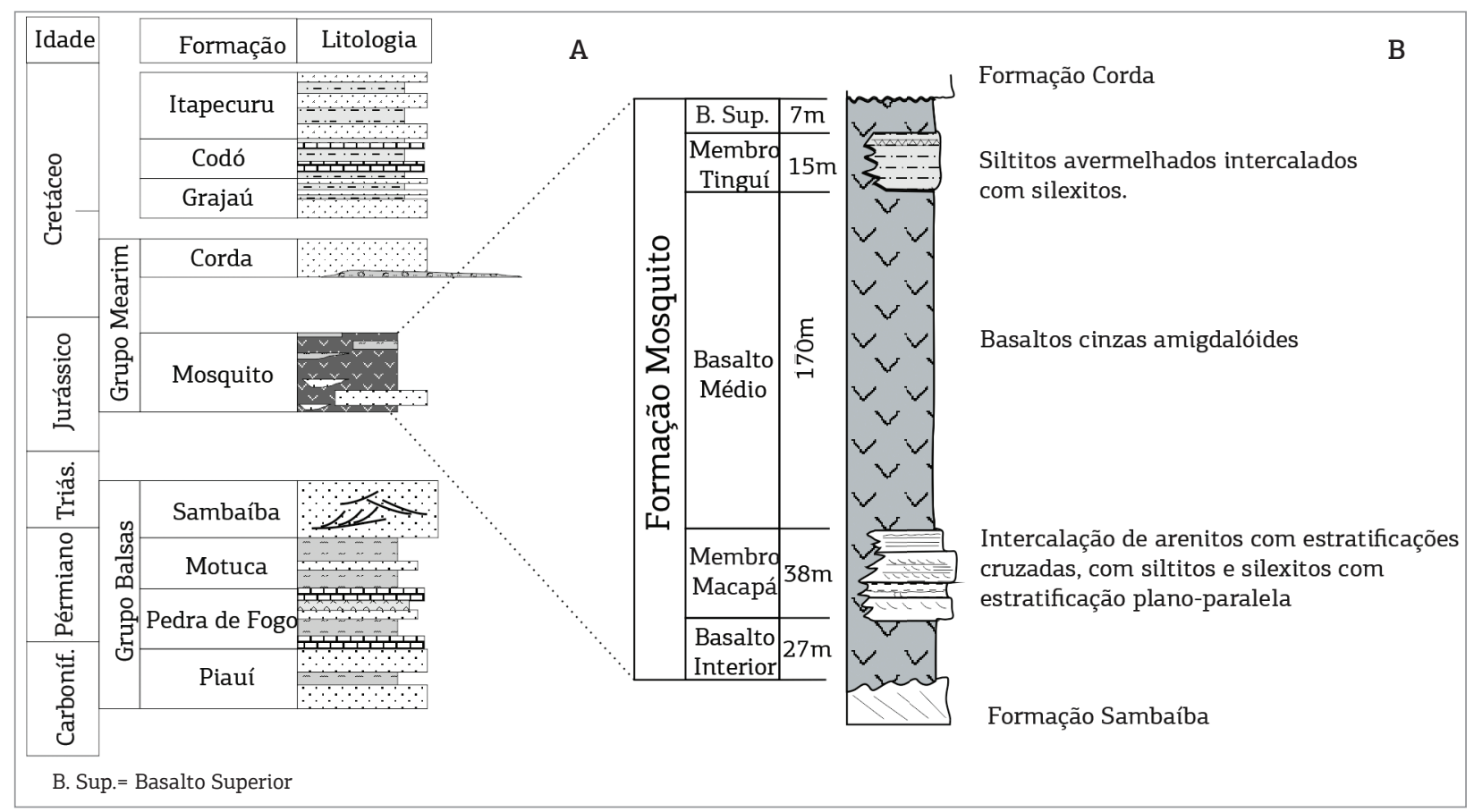

Figura 2. (A) Coluna estratigráfica esquematizada da Província Parnaíba na área de ocorrência da Formação Mosquito. (B) Estratigrafia da Formação Mosquito no vale do Rio Mosquito, Fortaleza dos Nogueiras - MA. Modificado de Aguiar (1971).

\section{RESULTADOS}

\section{Análise de fácies}

\section{Membro Macapá}

Esta unidade ocorre na base da Formação Mosquito entre as camadas de basalto inferior e basalto médio, Fig. 3. As melhores exposiçóes estão nas cachoeiras formadas pelos rios Macapá e Mosquito, na regiāo de Fortaleza dos Nogueiras - MA. Dentro desta sucessão, no vale do rio Mosquito (Fig. 4) ocorrem oito fácies (Tab. 1) agrupadas em três associaçôes faciológicas: (1) Associação de lençóis de areia com fluviais efêmeros; (2) Associação de playa siliciclástica; e (3) Associação de pequenas dunas eólicas com depósitos de interduna encharcada.

\section{Descrição das associaçôes faciológicas identificadas:}

1) Associação de lençóis de areia com fluviais efêmeros (ALF)

Descrição: Ocorre na parte basal da sucessão. Trata-se de intercalaçôes de camadas de arenitos com estratificação cruzada de baixo ângulo $(\mathrm{Ab})$ com laminação transladante subcrítica, com intercalaçóes menores de camadas espessas $(0,3-1 \mathrm{~m})$ de arenitos finos e médios com marcas onduladas supercríticas (Figura 5D) com registro dos foresets. Ocorrem também associadas camadas de arenitos com laminação corrugada e wavy.
Interpretação: Os arenitos com estratificação cruzada de baixo ângulo foram interpretados como construídos pela migração de marcas onduladas subcríticas de pequeno porte, causado pelo vento (wind ripple). A ocorrência de camadas com conjunto de laminaçóes cavalgantes supercríticas (Ao) é atribuída à migração de formas de leito de pequena amplitude em condiçóes de regime de fluxo inferior com lâmina de água de baixa profundidade (Allen 1984). O contato dessas fácies com aquelas de arenitos eólicos é difuso e não foram observadas camadas em forma de canal. Acredita-se que os fluxos subaquosos retrabalharam os lençóis de areias eólicas em episódios com um nível relativo do lençol freático elevado, sem gerar maior erosão nem acumulação com decantação de lama sobre as antigas formas de leito.

\section{2) Associação de playa siliciclástica (APS)}

Descrição: Estes depósitos observados em dois pacotes (Fig. 4A) dentro do Membro Macapá, consistem em camadas de 1 até $4 \mathrm{~m}$ de sucessóes de arenitos finos intercalados com depósitos heterolíticos (Fig. 5B). As camadas de arenito apresentam laminaçôes ou estratificaçôes corrugadas e irregulares, em uma escala de $1-4 \mathrm{~mm}$ (Ad). Internamente, são constituídas de marcas onduladas assimétricas de $2-5 \mathrm{~mm}$ de amplitude, feiçóes de pequenos domos ou saliências ligeiramente ovais com distribuição randômica e estratos paralelos corrugados e irregulares 
(Fig. 5E e 5F). São identificados localmente arenitos com marcas onduladas subaquosas com amplitudes de 1,0 a 2,0 mm (Ao). As camadas de heterolíticos ( $\mathrm{Hw}$ ) consistem em intercalaçóes de lâminas de arenitos finos, às vezes lamosos, com lâminas de lamitos argilosos, matéria orgânica e, localmente, lâminas delgadas $(<1 \mathrm{~mm})$ de evaporitos. Estes foram interpretados a partir da identificação de um tipo de calcedônia com elongação negativa que Pittman e Folk (1971) associam a ambientes evaporíticos (Fig. 5G). Tanto os lamitos quanto os evaporitos na diagênese foram substituídos por minerais silicosos como quartzo e calcedônia. Podem ser observadas camadas de arenitos com intraclastos silicificados. É bem comum a presença de nódulos com maior cimentação silicosa, geralmente elípticos com seu eixo maior paralelo à estratificação.

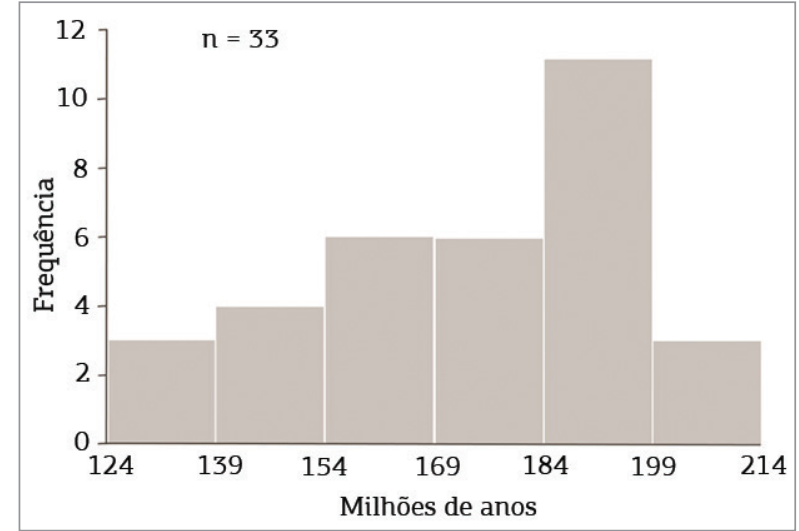

Figura 3. Histograma dos dados das datações radiométricas dos basaltos na área de Porto Franco, Grajaú Fortaleza dos Nogueiras e Carolina. Baseado em dados de Baksi e Archibald (1997), Fodor et al. (1990), Góes et al. (1993), Lima e Leite (1978) e Merle et al. (2011).

Tabela 1. Fácies e processos interpretados nas unidades interderrames associadas à Formação Mosquito. A localização dos pontos estudados encontra-se na Fig. 1

\begin{tabular}{|c|c|c|c|c|c|}
\hline \multicolumn{2}{|c|}{ Fácies } & \multirow{2}{*}{$\begin{array}{l}\quad \begin{array}{c}\text { Descrição das estruturas e } \\
\text { geometria externa. }\end{array} \\
\text { Arenitos finos a médios em } \\
\text { conjuntos de } 0,3 \text { a } 2 \text { m de } \\
\text { estratificações cruzadas } \\
\text { tangenciais com ângulos } \\
\text { de } 15 \text { a } 30^{\circ} \text {, marcadas pela } \\
\text { intercalação de lâminas } \\
\text { espessas e delgadas. Comum } \\
\text { laminação risco de agulha. }\end{array}$} & \multirow{2}{*}{$\begin{array}{l}\text { Processo Sedimentar } \\
\text { Migração e reativação de formas de } \\
\text { leito de dunas eólicas com forma 3D. } \\
\text { Ocorrem simultaneamente queda e } \\
\text { fluxo de grãos. }\end{array}$} & \multirow{2}{*}{$\begin{array}{c}\text { Associação } \\
\text { de fácies }\end{array}$} & \multirow{2}{*}{$\begin{array}{l}\text { Localidade } \\
1,2,3\end{array}$} \\
\hline $\mathrm{Aa}$ & $\begin{array}{l}\text { Arenitos com } \\
\text { estratificação } \\
\text { cruzada de } \\
\text { alto ângulo, } \\
\text { tangencial ou } \\
\text { acanalada }\end{array}$ & & & & \\
\hline $\mathrm{Ab}$ & $\begin{array}{l}\text { Arenitos com } \\
\text { estratificação } \\
\text { cruzada de } \\
\text { baixo ângulo }\end{array}$ & $\begin{array}{l}\text { Arenitos finos a médios } \\
\text { caracterizados por estratos } \\
\text { transladantes cavalgantes } \\
\text { subcríticos. }\end{array}$ & $\begin{array}{l}\text { Carga por tração pelo vento. Migração } \\
\text { de marcas onduladas cavalgantes, } \\
\text { subcríticas e transladantes. }\end{array}$ & $\begin{array}{l}\text { Lençóis de } \\
\text { areia } \\
\text { dunas eólicas }\end{array}$ & 1,3 \\
\hline Ad & $\begin{array}{l}\text { Arenitos com } \\
\text { estruturas de } \\
\text { adesão }\end{array}$ & $\begin{array}{l}\text { Arenitos finos distribuídos em } \\
\text { estratos horizontais corrugados } \\
\text { (wrinkle marks) ou com marcas } \\
\text { onduladas de adesão. }\end{array}$ & $\begin{array}{l}\text { Formam-se pela aderência de grãos } \\
\text { de areia sopradas em uma superfície } \\
\text { úmida. As marcas onduladas de adesão } \\
\text { formam-se por adesão de areia no } \\
\text { dorso da forma de leito enquanto os } \\
\text { estratos plano-paralelos pela adesão de } \\
\text { areia sem geração de formas de leito. }\end{array}$ & $\begin{array}{l}\text { Interduna } \\
\text { encharcada / } \\
\text { playa } \\
\text { siliciclástica }\end{array}$ & 1 \\
\hline Ao & $\begin{array}{l}\text { Arenitos } \\
\text { com marcas } \\
\text { onduladas } \\
\text { subaquosas }\end{array}$ & $\begin{array}{l}\text { Arenitos finos em camadas de } \\
2 \text { até } 5 \mathrm{~cm} \text { de espessura. Marcas } \\
\text { onduladas assimétricas com } \\
\text { amplitude menores que } 2-4 \mathrm{~cm} \text {. }\end{array}$ & $\begin{array}{l}\text { Carga por tração em regime de fluxo } \\
\text { inferior. Migração de formas de leito de } \\
\text { pequeno porte em domínio subaquoso. }\end{array}$ & $\begin{array}{l}\text { Interduna } \\
\text { inundada }\end{array}$ & 1 \\
\hline $\mathrm{Ai}$ & $\begin{array}{l}\text { Arenitos } \\
\text { intraclásticos }\end{array}$ & $\begin{array}{l}\text { Camada de } 10 \mathrm{~cm} \text { de arenitos } \\
\text { com intraclastos de lama de até } \\
3 \mathrm{~cm} \text {. (Fig. } 5 \mathrm{H} \text { ) }\end{array}$ & $\begin{array}{l}\text { Carga por tração subaquosa que } \\
\text { retrabalha lama do depósito anterior } \\
\text { que sofreu dessecação e fraturamento. }\end{array}$ & $\begin{array}{l}\text { Playa } \\
\text { siliciclástica }\end{array}$ & 1 \\
\hline $\mathrm{Hw}$ & $\begin{array}{l}\text { Heterolíticos } \\
\text { de arenitos } \\
\text { e lamitos } \\
\text { silicificados }\end{array}$ & $\begin{array}{l}\text { Intercalações de lâminas de } \\
\text { arenitos e lamitos, fortemente } \\
\text { silicificados, formando } \\
\text { laminação wavy. }\end{array}$ & $\begin{array}{l}\text { Decantação de lama com períodos de } \\
\text { carga por tração e deposição de areia. }\end{array}$ & $\begin{array}{l}\text { Interduna } \\
\text { inundada }\end{array}$ & 1 \\
\hline Hf & $\begin{array}{l}\text { Heterolíticos } \\
\text { finos com } \\
\text { laminação } \\
\text { plano-paralela }\end{array}$ & $\begin{array}{l}\text { Intercalações de camadas muito } \\
\text { delgadas de siltitos e argilitos, } \\
\text { eventualmente com crostas } \\
\text { de evaporitos e gretas de } \\
\text { dessecação. }\end{array}$ & $\begin{array}{l}\text { Decantação de sedimentos finos, com } \\
\text { períodos de dessecação com dessecação } \\
\text { e precipitação de evaporitos. }\end{array}$ & Playa lake & 1 \\
\hline $\mathrm{Hl}$ & $\begin{array}{l}\text { Heterolíticos } \\
\text { laminitos } \\
\text { algáceos/arenitos }\end{array}$ & $\begin{array}{l}\text { Intercalações de camadas muito } \\
\text { delgadas de laminitos algáceos } \\
\text { silicificados e arenitos finos }\end{array}$ & $\begin{array}{l}\text { Processos biogênicos relacionados à } \\
\text { formação de tapetes algáceos (algal } \\
\text { mat) em ambientes aquosos rasos }\end{array}$ & $\begin{array}{l}\text { Margem de } \\
\text { lago playa }\end{array}$ & 4 \\
\hline
\end{tabular}




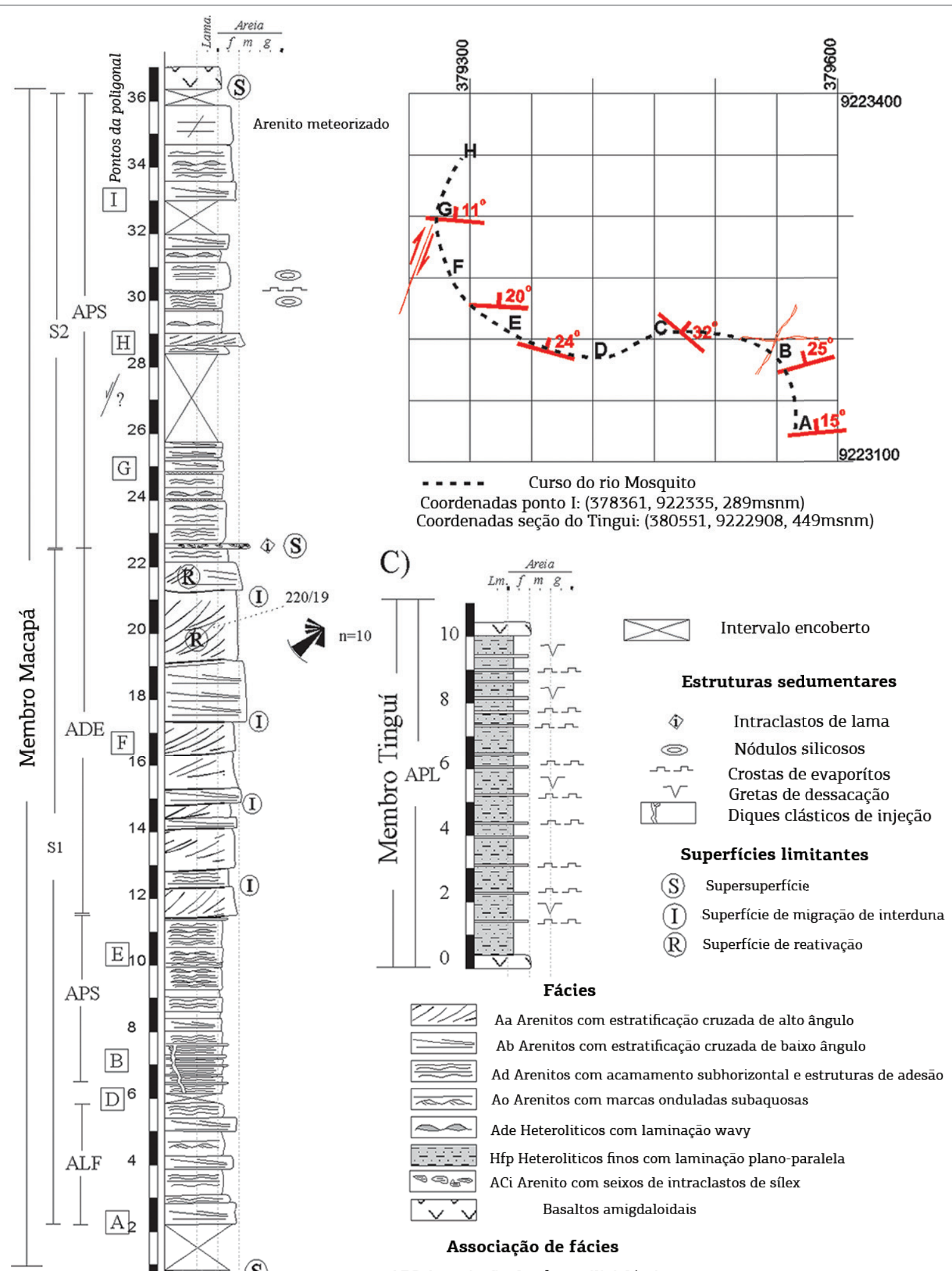

APS Associação de playa siliciclástica

ALF Associação de lençóis de areia com fluviais efêmeros

ADE Associação de dunas eólicas com depósitos de interduna encharcada

APL Associação de playa lake

Figura 4. Colunas estratigráficas da Formação Mosquito no vale do rio Mosquito, Fortaleza dos Nogueiras - MA. (A) Coluna estratigráfica levantada do Membro Macapá; na esquerda se observam as interpretações de sucessões e associações de fácies. (B) Mapa esquemático com a poligonal localizando os afloramentos do Membro Macapá. (C) Coluna estratigráfica do Membro Tinguí no vale do rio Mosquito. 


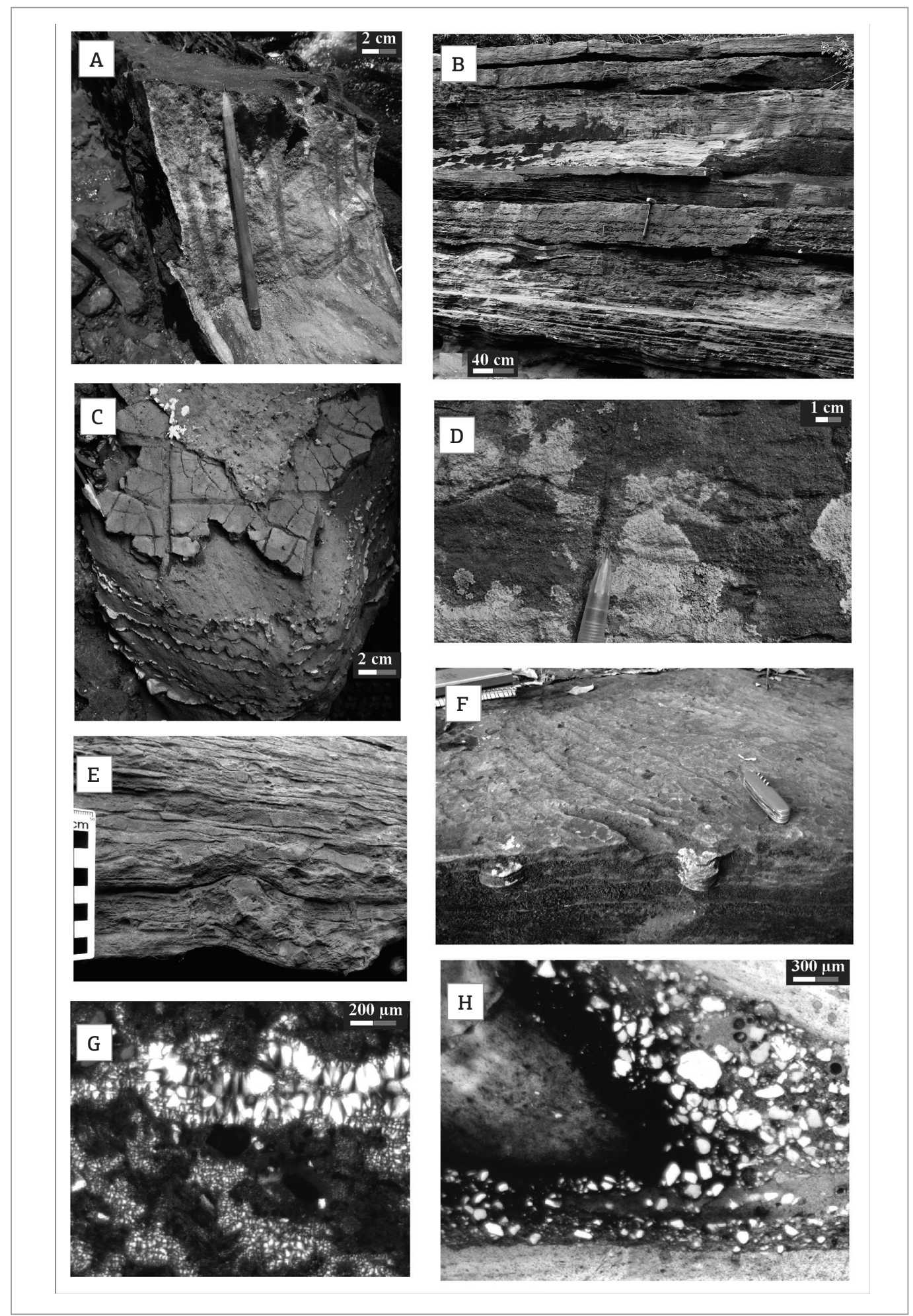

Figura 5. Fácies da Formação Mosquito no vale do rio homônimo. (A) Detalhe de dique clástico com segregação granular paralela ao plano da fratura, base do Membro Macapá. (B) Sucessão de fácies da associação de playa. Notar as laminações onduladas a planas, irregulares e corrugadas. (C) Fácies heterolíticas finas com interdigitações de crostas de evaporitos e com gretas de dessecação na superfície de um estrato de lamito, Membro Tinguí. (D) Marcas onduladas subaquosas da associação de fácies de interdunas úmidas, na base do Membro Macapá. (E) Fácies heterolíticas arenito-silexito em vista de corte com estratos subhorizontais corrugados, nódulos e forte diagênese. (F) Marcas onduladas de adesão em planta, notar no corte que os estratos se apresentam horizontais e corrugados. (G) Fotomicrografia com lâminas de calcedônia com elongação anômala que tem sido associada a ambientes evaporíticos. (H) Fotomicrografia da fácies de arenitos intraclásticos. Notar arenitos lamosos no meio de seixos silicificados de lamito. 
Interpretação: Os arenitos finos com estratificação corrugada e irregular (Ad) são interpretados como marcas onduladas de adesão, estratos plano-paralelos de adesão e estruturas corrugadas (wrinkle structures). As estruturas de adesão são produzidas pela aderência de grãos secos de areia soprados pelo vento em superfícies deposicionais molhadas (Kocurek \& Fielder 1982). As feiçôes internas destacamse por seu aspecto finamente laminado, irregular e corrugado. As estruturas corrugadas são interpretadas como produto de crescimento de esteiras microbianas (microbial mats) (Porada \& Bouougri 2007). A presença localizada de arenitos com marcas onduladas subaquosas de crista reta (Ao) é atribuída à migração de marcas onduladas de corrente (Allen 1984). As camadas de estratos heterolíticos (Hw) foram geradas em condiçôes flutuantes de energia e do nível da lâmina de água, as quais propiciariam decantação de finos em condiçóes de baixa energia, seguidas de deposição por carga de tração de areia durante o aumento nas condiçôes de fluxo. O rebaixamento do lençol freático foi responsável pela dessecaçáo evidenciada pela formação de gretas de contração e, eventualmente, precipitação de minerais evaporíticos. As camadas na base da associação de arenitos com abundantes intraclastos silicificados (Fig. $5 \mathrm{H})$ foram interpretadas como estruturas de deposito residual, associado a um episódio de inundação que arrancou e redepositou desordenadamente os fragmentos de lama, produto de uma decantação que posteriormente, na diagênese, foram substituídos por minerais do grupo da sílica, tais como calcedônia e quartzo. O conjunto dessas fácies foi interpretado como depósitos de playa sensu (Briere 2000), ou seja, regiōes planas num clima árido e quente, com forte predomínio de tempo seco, mas com episódios de inundação e posterior dessecação.

3) Associação de campos de dunas eólicas com depósitos de interduna encharcada (ADE)

Descrição: Esta associação, presente na parte média do Membro Macapá (Fig. 4A), consiste em $11 \mathrm{~m}$ de arenitos de granulação fina a média, coloração amarela avermelhada, com gráos bem selecionados, arredondados e esféricos. Nesta associação as fácies se diferenciam principalmente pela inclinaçâo das estratificaçôes cruzadas. $\mathrm{Na}$ fácies de estratificaçôes cruzadas de alto ângulo (Aa) (Tab. 1), os estratos variam de 15 a $30^{\circ}$ de inclinação e têm espessura entre 1 e $5 \mathrm{~cm}$. Estes depósitos são compostos de intercalaçóes de lâminas de 2 $4 \mathrm{~mm}$ de arenitos médios, com estratos de 1 a $3 \mathrm{~cm}$ de arenitos finos. Esta fácies tem geometria em cunha, cujo lado menor aponta para a base do conjunto. Por outro lado, a fácies $(\mathrm{Ab})$ consta de arenitos de granulação fina a média com estratificaçôes cruzadas de baixo ângulo compostas de estratos transladantes subcríticos. A fácies (Ad) corresponde a uma intercalação de camadas com estratificação horizontal corrugada. Em geral trata-se de estratos delgados de 1 a $3 \mathrm{~cm}$ de arenitos finos e muito finos.

As fácies $\mathrm{Aa}$ e $\mathrm{Ab}$ ocorrem em conjuntos de estratificaçóes cruzadas de 0,4 até $2 \mathrm{~m}$ de espessura. Estes às vezes estão separados por superfícies inclinadas que os cortam, separando os conjuntos, mudando levemente as direçôes de mergulho das cruzadas. Estes conjuntos apresentam-se truncados, ocorrendo só a parte inferior da fácies $\mathrm{Aa}$, ou apenas aparecer a fácies $\mathrm{Ab}$. Nesta associação ocorrem os seguintes tipos de conjuntos: uns com fácies $(\mathrm{Aa})$ e $(\mathrm{Ab})$ e outros com as fácies $(\mathrm{Ab})$ e $(\mathrm{Ad})$, (Figs. 6A e B). Entre estes conjuntos se apresentam dois tipos de relaçóes: 1) contato inferior das cruzadas (Aa e Ab, o seja, dunas) é planar abrupto com as fácies (Ad) e encontra-se limitado por superfícies de interdunas; e 2) depósitos das fácies (Aa) e (Ab) encontram-se interdigitados com os depósitos das fácies (Ad) (Fig. 6C).

Interpretação: Dentro da fácies (Aa) foram interpretados os depósitos de queda e fluxos de grãos que correspondem às intercalaçóes de lâminas e estratos delgados, respectivamente. $\mathrm{Na}$ base da seção, na fácies $(\mathrm{Ab})$ ocorre a migração e cavalgamento de pequenas formas de leito ondulada que geraram as laminaçóes transladantes subcríticas. Então, os conjuntos com estas fácies foram produto da migração de dunas eólicas provavelmente crescentes com cristas ligeiramente onduladas. O agrupamento das fácies $(\mathrm{Aa})$ e $(\mathrm{Ab})$ corresponde com as dunas eólicas, onde na parte superior da seção localiza-se (Aa) e na base da seção a fácies $(\mathrm{Ab})$.

As estratificaçóes corrugadas da fácies (Ad) foram interpretadas como estruturas de adesão (Tab. 1). Estas estruturas ocorrem nas áreas de interduna encharcada, que são constituídas basicamente pela fácies (Ad).

Os conjuntos de pequena espessura com as fácies das dunas eólicas intercalados com a fácies (Ad) de interduna encharcada sugerem um ambiente com migração de dunas eólicas de pequeno porte no meio de áreas de interdunas encharcadas. Por outro lado, as camadas de elementos de dunas truncadas e as estruturas de adesão são prova de uma forte influência do lençol freático. O fato destas duas fácies de dunas (Aa e $\mathrm{Ab}$ ) se encontrarem localmente com o depósito da base da seção interdigitado com as fácies de arenitos sub-horizontais com estruturas de adesão (Fig. 6C), pode ser interpretado naquele conjunto especifico, que a migração das dunas foi contemporânea com a sedimentação da interduna (Mountney \& Thompson 2002). As superfícies horizontais que limitam os conjuntos podem ser interpretadas como as superfícies produzidas pela migração da interduna. 


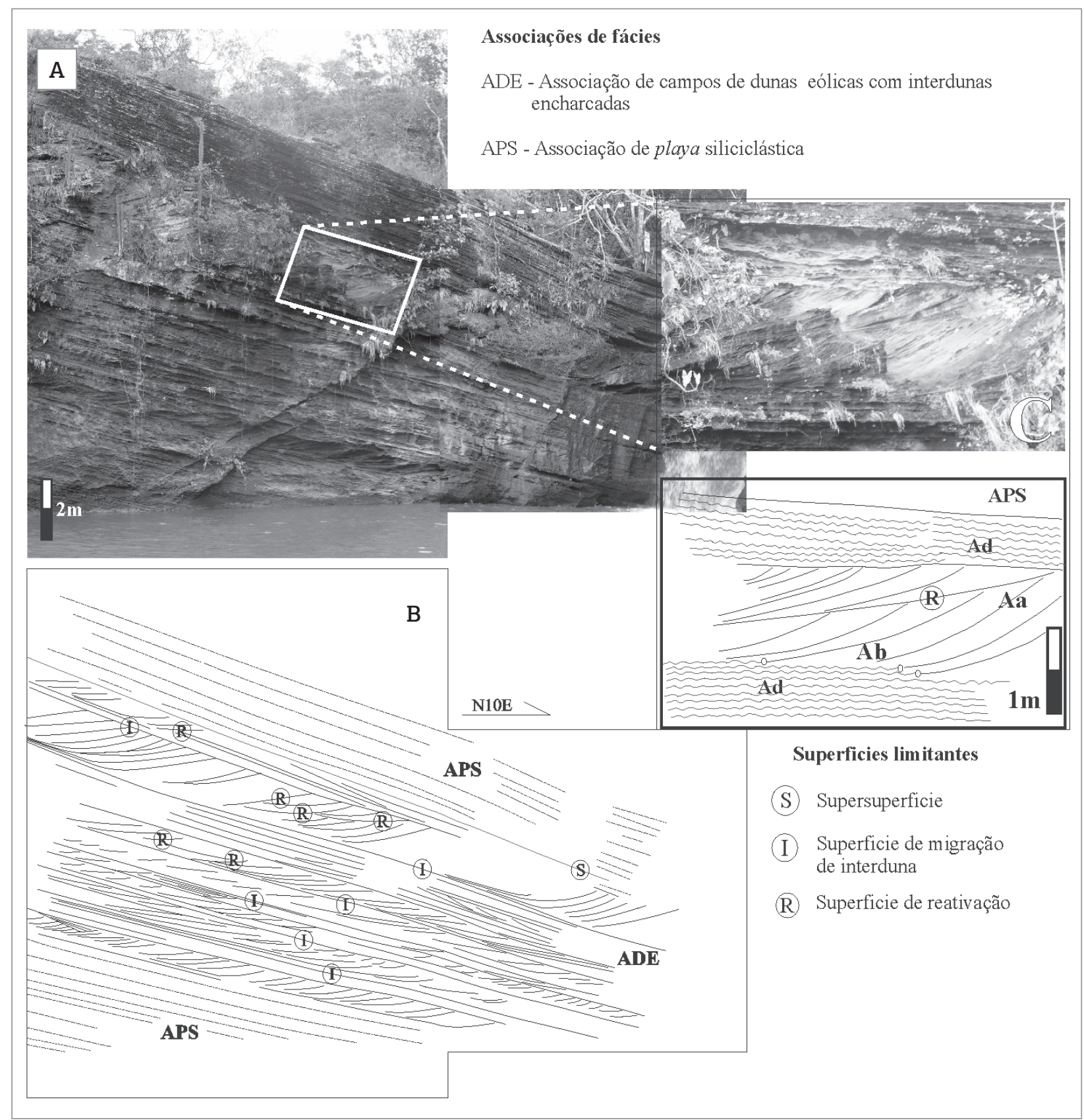

Figura 6. Fácies e superfícies limitantes do maior afloramento do Membro Macapá no vale do rio Mosquito, o afloramento vai dos pontos $\mathrm{E}$ até $\mathrm{H}$ da poligonal (Fig. 4B). (A e B) Fotomosaico e interpretação com as associações de fácies interpretadas e as superfícies limitantes. (C) Detalhe de um tipo de relação entre a fácies Ab das dunas eólicas e a fácies Ad da interduna encharcada. Note que, neste caso, a relação é interdigitada.

\section{Diques Clásticos}

A base do Membro Macapá apresenta-se localmente fraturada e cortada por diques clásticos, os quais têm um arranjo conjugado, e alguns mostram internamente estrutura de fluxo com segregação granular paralela ao plano do dique (Fig. 5A). Esta feição é interpretada como produto da injeção de areia em estado fluidificado (Jolly \& Lonergan 2002), seguido da percolação vertical e transporte de grãos por zonas de fissuras, geradas por distensão. Essa percolação ascendente gerou um fluxo de areia e água, que segregou por granulometria os sedimentos. Esta estrutura é penecontemporânea é atribuída a um evento sísmico de intensidade considerável. As fraturas que foram injetadas pelo depósito devem ser coetâneas da sedimentação. Foram tomados alguns dados de juntas associadas a esses diques (Fig. 7). Segundo os dados obtidos pode-se sugerir que a distensão da tectônica geradora tinha uma direção NNE-SSW. 


\section{Membro Tinguí}

Dentro da sucessão observada do Membro Tinguí foi interpretada uma única associação de fácies de playa lake.

Descrição: Trata-se de aproximadamente $15 \mathrm{~m}$ de uma sucessão monótona (Fig. 4C) de interposiçôes de camadas de argilitos vermelhos com siltitos cinza avermelhados e crostas silicificadas. Os argilitos apresentam-se finamente laminados com gretas de dessecação (Fig. 5C) e flocos de lama. As intercalaçôes de siltitos correspondem a lâminas horizontais com espessuras superiores a $3 \mathrm{~mm}$.

Interpretação: A predominância de camadas de argilitos foi gerada por decantação em águas tranquilas com esporádicas flutuaçóes no aporte de sedimento em suspensão, formando lâminas de material detrítico na fração silte. O rebaixamento do nível da lâmina de água é evidenciado pelas gretas e estruturas geradas em condições de dessecação, períodos nos quais poderia ocorrer a precipitação de minerais evaporíticos, interpretados a partir de crostas silicificadas com presença de calcedônia com elongação anômala.

\section{Unidades interderrames de pouca espessura e continuidade lateral}

No mapeamento da região foram identificadas diversas camadas sedimentares sem continuidade lateral, depositadas em paleodepressóes formadas sobre os derrames basálticos da Formação Mosquito. Esta situação impossibilita a correlação entre estas e as demais camadas registradas em outras localidades. Apesar disso, foram destacadas, por suas características, duas sucessóes sedimentares distantes cerca de $50 \mathrm{~km}$ (Fig. 1).

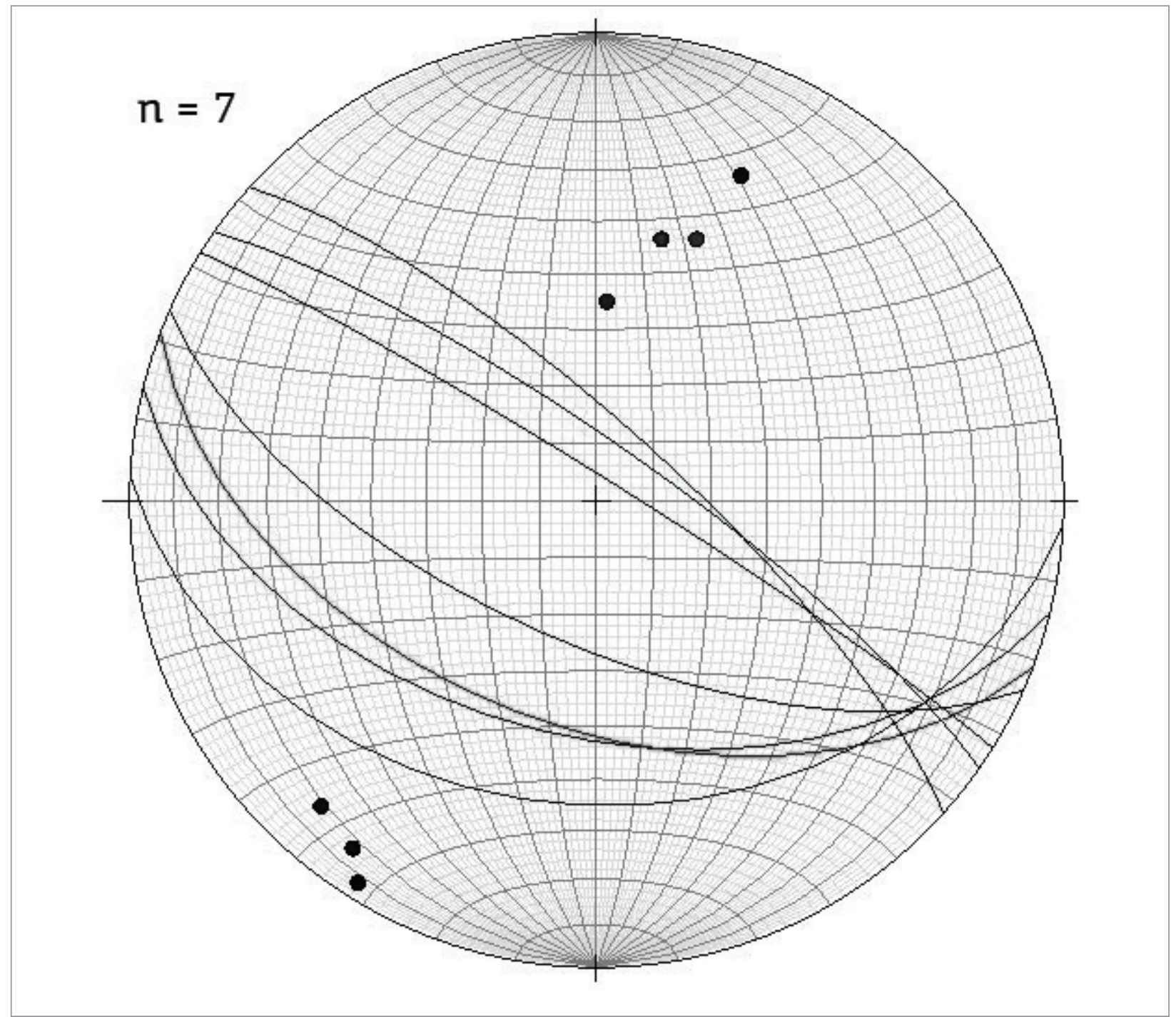

Figura 7. Planos e polos dos planos das juntas associadas a diques clásticos no vale do Rio Mosquito. Os dados foram obtidos no ponto B da poligonal (Fig. 4B). 


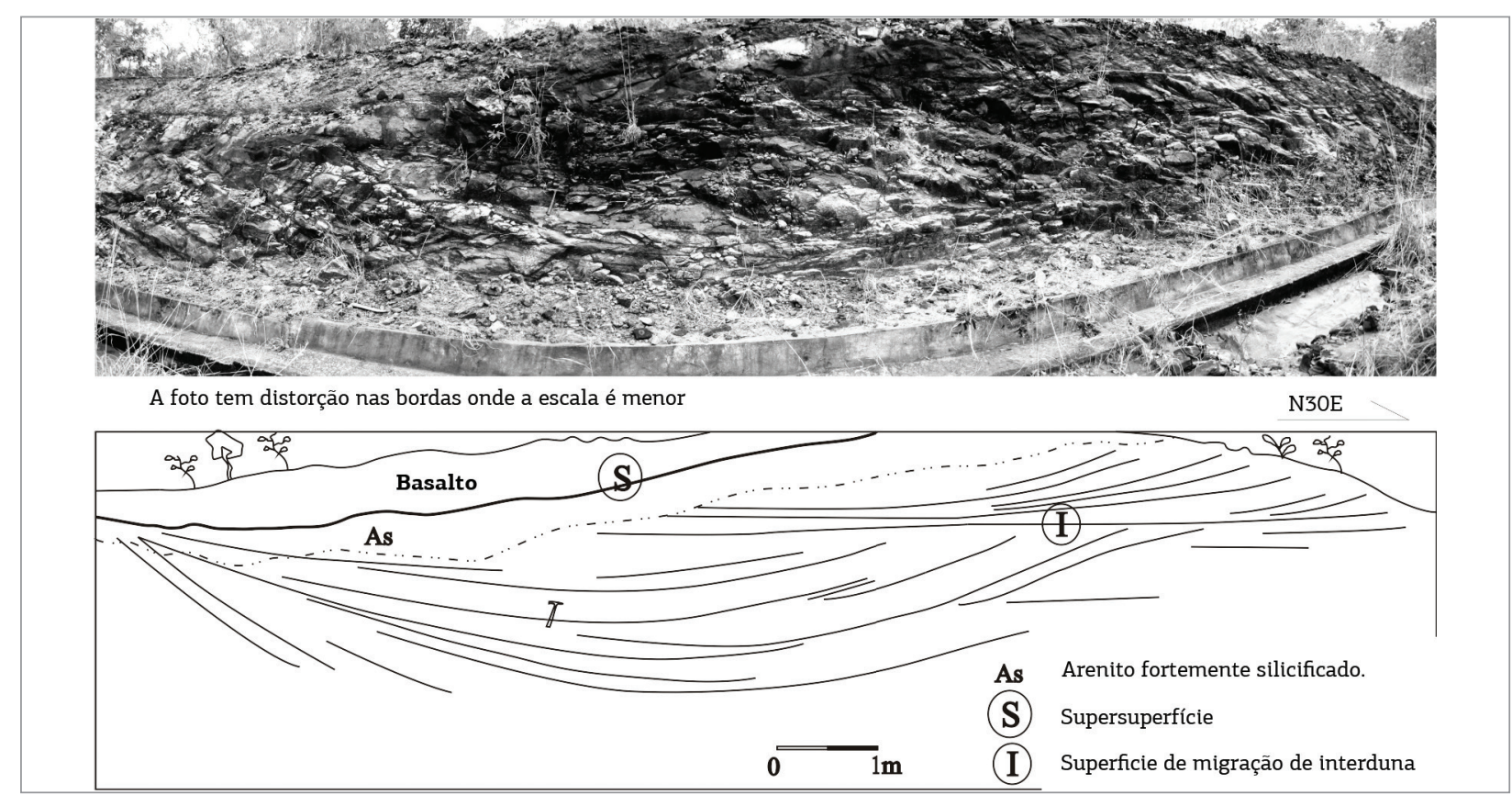

Figura 8. Fotomosaico de afloramento de interderrame isolado na região de Três Buritis, ao sul de Fortaleza dos Nogueiras MA (Fig. 1). Os fluxos basálticos dos derrames alojaram-se nos paleorrelevos sobrepostos aos arenitos interderrames.

\section{Localidade de Três Buritis (estrada entre Fortaleza dos Nogueiras e Balsas)}

\section{Associaçâo de dunas eólicas}

Descrição: Trata-se de um arenito com granulometria variando de fina a média, com estratificação cruzada acanalada de grande porte (Aa), com uma continuidade lateral de pelo menos $30 \mathrm{~m}$ (Fig. 8). Uma superfície horizontal plana separa os sets enquanto o contato superior do pacote sedimentar arenoso com rocha basáltica é irregular e marcado pela presença de uma faixa com aproximadamente $50 \mathrm{~cm}$ de espessura de arenito fortemente silicificado. Lateralmente, os arenitos com estratificação cruzada de alto ângulo passam a arenitos com estratificação cruzada de baixo ângulo (Ab).

Interpretação: Corresponde a uma associação de dunas eólicas onde ocorrem os depósitos de queda e fluxo de grãos, bem como estratificaçôes cruzadas de baixo ângulo com marcas onduladas transladantes. Os arenitos com estratificaçôes cruzadas de alto ângulo junto com feiçôes típicas de sedimentação eólica, como as marcas onduladas cavalgantes transladantes subcríticas e presença de grãos bem selecionados e arredondados são sugestivos de migraçóes de dunas eólicas no campo de dunas. A superfície horizontal plana é interpretada como uma superfície de migração da interduna. E por fim, a superfície de contato irregular (arenito-basalto) corresponde a uma feição de erosão que ocorreu anteriormente ao derrame basáltico, o qual preencheu as depressóes do paleorrelevo. A silicificaçáo do arenito no contato com os basaltos está relacionada com a dissoluçáo do quartzo, na presença de fluidos ricos em álcalis associados ao magmatismo.

\section{Localidade da Fazenda Murici (estrada entre Fortaleza dos Nogueiras e Nova Colinas)}

\section{Associação de Lençóis de areia}

Descrição: Consiste em arenitos com estratificação cruzada de baixo ângulo $(\mathrm{Ab})$ separados por uma superfície sub-horizontal. O conjunto inferior em contato com o derrame basáltico é composto por arenitos de granulação fina a média, localmente grossa, com estratificação sub-horizontal e feiçóes do tipo risco de agulha em lâminas de 1 a $3 \mathrm{~mm}$. O conjunto superior tem estratificação cruzada de baixo ângulo associado a marcas onduladas transladantes.

Interpretação: $\mathrm{O}$ pacote arenoso com estratificação cruzada de baixo ângulo corresponde a depósitos gerados por tração, formando marcas transladantes subcríticas. As laminaçóes tipo risco de agulha são produto da cimentação diferencial em níveis com segregação granular penecontemporânea, devido ao peneiramento cinético no momento em que o vento passa sobre os grãos já depositados. O conjunto superior com estratificaçáo cruzada de baixo ângulo corresponde a formas de leito plano sobre as quais migravam marcas onduladas. A interpretação como uma associação de lençóis de areia é reforçada pela ausência de dunas maiores e, a ausência de feiçôes diagnósticas da presença de umidade. Este afloramento foi afetado por uma tectônica deformadora distensiva gerando falhas normais que deslocam blocos de arenito e os póem no mesmo nível topográfico dos basaltos (Fig. 9). 


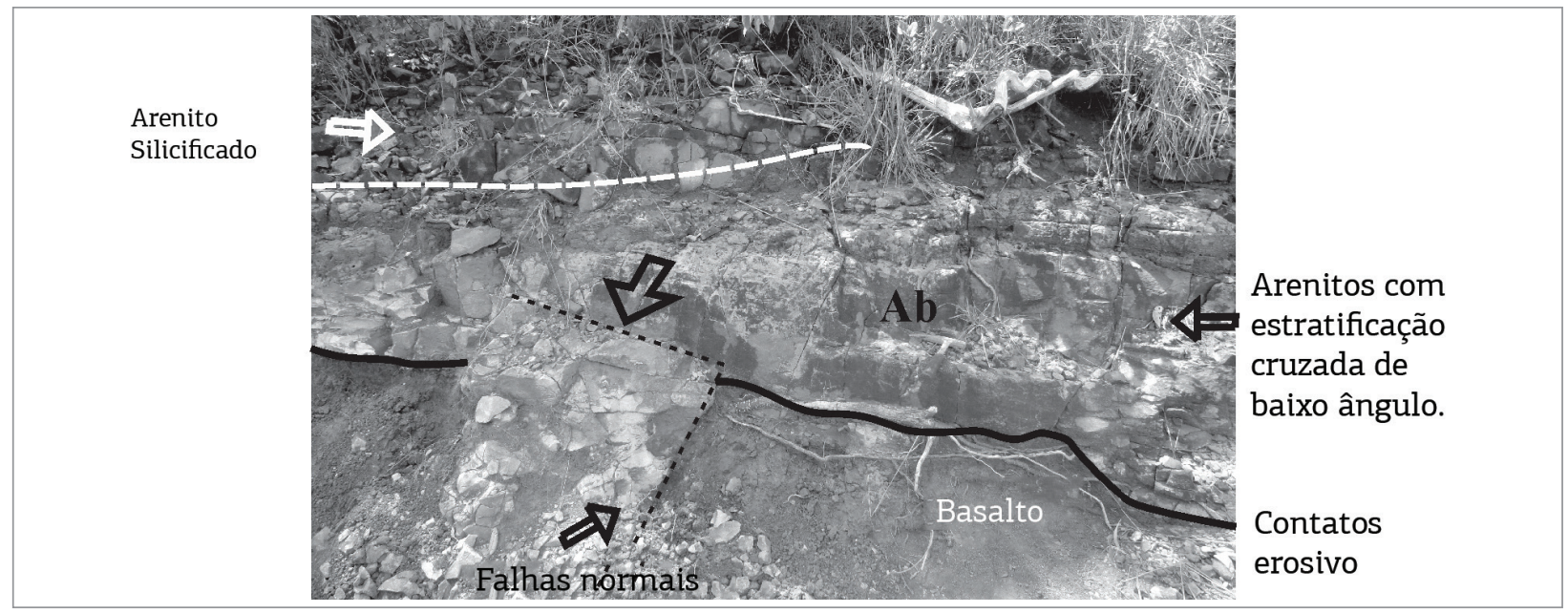

Figura 9. Foto de afloramento de interderrame isolado na Fazenda Murici, entre Novas Colinas e Fortaleza dos Nogueiras - MA. Encontram-se os arenitos sobre paleorrelevo, sendo o contato superior também erosivo marcado pela presença de arenito silicificado no topo dos sedimentos. Note falhas normais de alguma fase de tectônica deformadora.

\section{DISCUSSÃO}

\section{Os afloramentos isolados e as supersuperfícies arenito-basalto}

A deposição das unidades interderrames da Formação Mosquito ocorreu num ambiente tectônico ativo que gerou episódios de subsidência tectônica, de sismicidade e magmatismo. Os fluxos basálticos da Formação Mosquito foram atribuídos a numerosos pulsos magmáticos de idades diferentes, mas relativamente próximas entre si (Góes et al. 1993, Fodor et al. 1990, Baksi \& Archibald 1997). Isso tornou possível que cada novo fluxo de lavas que se espalhava pelos baixos topográficos gerasse uma nova paleotopografia, além dos novos esforços pela tendência à isostasia. Assim, em pequenas e isoladas áreas gerava-se espaço para a acumulação de sedimentos que segundo o aporte sedimentar e as condiçóes aerodinâmicas, acumulavam-se tanto depósitos eólicos com associaçôes de fácies de lençóis de areia como depósitos com associaçōes de dunas eólicas ou de lagos e playas terrígenos. Posteriormente, outro fluxo basáltico interrompia a sedimentaçâo e gerava uma nova paisagem. Os afloramentos tanto dos Membros Macapá e Tinguí, no vale do rio Mosquito, quanto aqueles isolados que se encontram espalhados pela área de estudo, dificilmente podem ser correlacionados e provavelmente estejam separados por hiatos estratigráficos.

Mesmo que a maior parte das supersuperfícies representem períodos de não deposição ou erosão, existem também casos onde uma mudança no ambiente deposicional gera uma interrupção na acumulação de depósitos eólicos (Kocurek \& Havholm 1993). Portanto, os limites entre as acumulaçôes de lava e areia são todos considerados supersuperfícies, pois com ou sem hiato estratigráfico interromperam a acumulação de depósitos eólicos. Casos deste tipo de supersuperfícies no mundo são descritos por Clemmensen (1988) para rochas pré-cambrianas na Groenlândia, por Mountney et al. (1999) na Formaçấo Ejto na Namibia e por Scherer (2002) na Formação Botucatu na Bacia de Paraná.

Conforme já observado por Cunha e Carneiro (1972) a primeira supersuperfície ocorre entre a Formação Sambaíba, Triássico da Província Parnaíba, e os derrames basálticos da Formação Mosquito. Esta superfície representa uma discordância, já que os basaltos encontram-se acumulados sobre uma paleotopografía. Esta paleotopografia está marcada por uma superfície que corta diferentes níveis e conjuntos de formas de leito das dunas da Formação Sambaíba.

A supersuperfície do topo da unidade basáltica representa também um hiato estratigráfico. Este contato é erosivo e os basaltos estão sendo recobertos por diferentes níveis estratigráficos, incluindo conglomerados da base da Formação Corda na área de Formosa da Serra Negra, e por arenitos lamosos da Formação Grajaú na cidade homônima.

Nas localidades da Fazenda Murici e Três Buritis ocorrem camadas de $<5 \mathrm{~m}$ de espessura de arenitos eólicos com formaçáo de dunas e sem evidências da presença de umidade no momento da deposição. Estes afloramentos, pela sua posição estratigráfica, situam-se nas proximidades da base da Formação Mosquito. As relaçôes de contato desses arenitos tanto na base quanto no topo são erosivas. Por outro lado, na parte média-superior da Formação Mosquito, como por exemplo no Membro Tinguí, no afloramento da Chapada da Galheira e em outros pequenos afloramentos da área de Nova Colinas, foram observadas sucessōes de siltitos, lamitos e laminítos algáceos. Estas fácies atribuídas a lagos e margem de lagos são evidências da presença de umidade. Assim, o nível relativo do lençol freático oscilava 


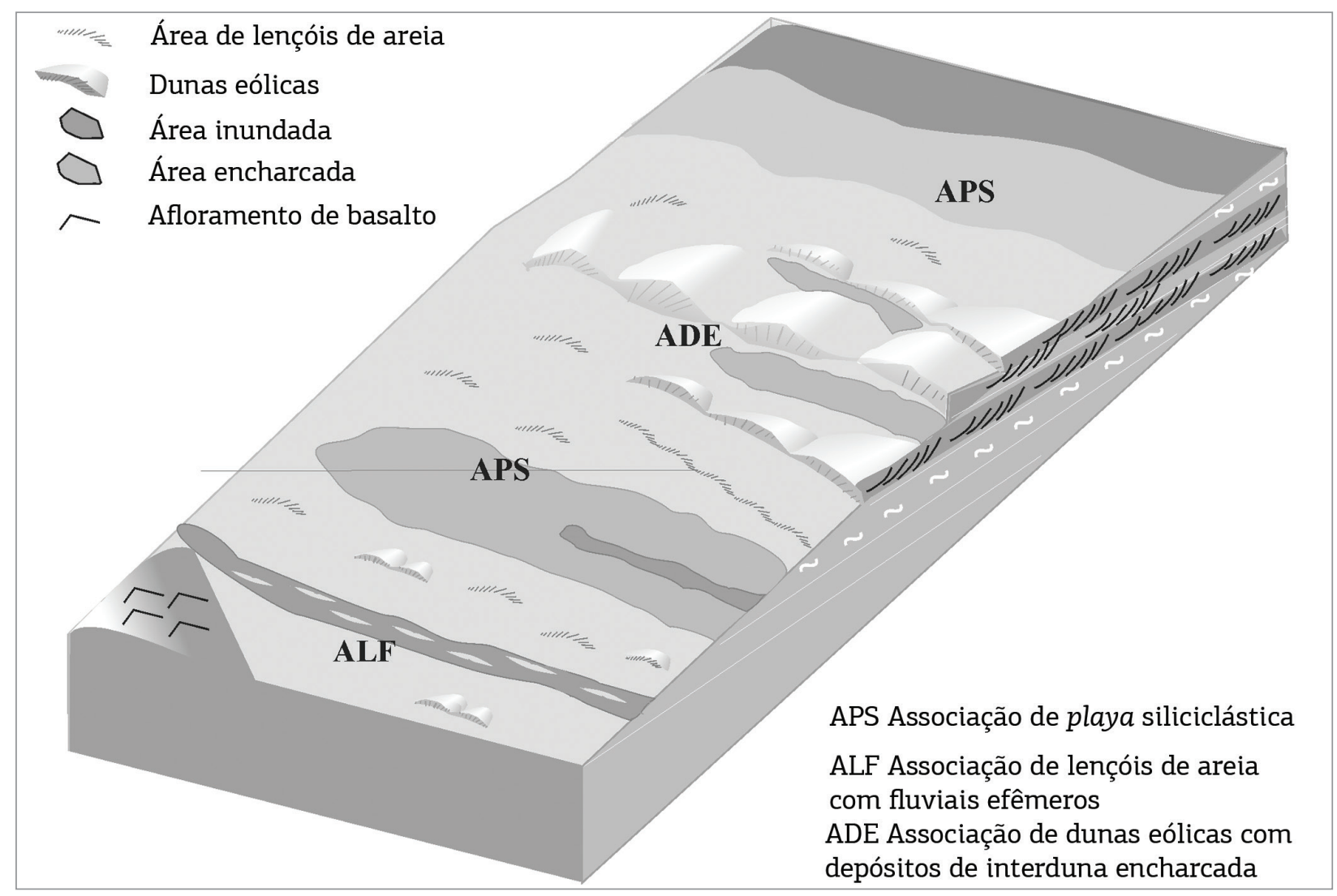

Figura 10. Bloco diagrama esquemático da interpretação esquemática paleoambiental do Membro Macapá da Formação Mosquito. Na parte inferior da figura, observa-se a associação de fácies de lençóis de areia com pequenas dunas e fluviais efêmeros. Logo acima observa-se a associação de margem de lago, logo as interdunas secas, os campos de dunas com interdunas encharcadas e finalmente a margem de playa lake do topo do Membro Macapá. Note a direção de migração dos conjuntos de dunas e as feições do empilhamento.

fracamente gerando as intercalaçóes de processos de decantação e dessecação. Então, embora não seja possível fazer correlaçóes estratigráficas dos afloramentos espalhados da Formação Mosquito, acredita-se que exista diferença entre os interderrames na base e no topo da unidade. Essa diferença basicamente pode corresponder a uma mudança na disponibilidade sedimentar que foi maior na base, permitindo a migração e a preservação de dunas eólicas.

\section{O Membro Macapá}

Estudos de sistemas deposicionais eólicos úmidos, tais como aqueles realizados por Kocurek (1981), Pulvertaft (1985), Fryberger (1990), Kocurek e Havholm (1993), Herries (1993), Mountney e Thompson (2002), Mountney e Jagger (2004) ressaltam a importância do lençol freático na acumulação deste tipo de ambientes deposicionais.

As associaçôes de fácies e seu arranjo dentro de uma sucessão de um sistema eólico refletem a culminação de um conjunto de eventos circunstanciais, que possibilitam a preservação no registro estratigráfico de um deposito eólico. Para isso, o depósito tem que estar abaixo da superfície de acumulação. Um depósito eólico acima desta superfície é considerado ainda em transporte, já que este está sujeito a ser erodido e continuar sendo transportado pelo vento (Kocurek \& Havholm 1993, Mountney 2006). Em um sistema eólico úmido, a acumulação ocorre como uma consequência, tanto da migração e cavalgamento das formas de leito, quanto pela presença de umidade. A areia úmida é dificilmente incorporada ao vento, enquanto a areia seca é facilmente levada por este. $\mathrm{O}$ nível do lençol freático controla a presença de umidade, portanto controla também o nível da superfície de acumulação. Assim, dentro de um sistema deposicional eólico úmido, o aumento progressivo do nível do lençol freático é o mecanismo básico para que acumulaçôes tanto de dunas como de interdunas sejam preservadas, ou seja, fiquem abaixo da superfície de acumulação (Hummel \& Kocurek 1984, Mountney \& Thompson 2002).

A sucessão sedimentar do Membro Macapá (Fig. 4A) começa com intercalaçóes de depósitos de lençóis de areia que mudavam de secos a encharcados e inundados (ALF), como resposta provavelmente sazonal ao aumento do lençol freático. No topo ocorrem associações de fácies de dunas 
eólicas com depósitos de interduna encharcada. A passagem entre estas duas associações de fácies ocorre em caráter transicional. Dentro da associação de fácies do topo (ADE), o fato de se observar os conjuntos de dunas eólicas truncados, junto com depósitos de interdunas com estruturas de adesão, são prova da forte influência do lençol freático. Durante períodos de rápido aumento do nível do lençol freático, a superfície de acomodação subia e parte das dunas ficava sob aquela superfície, as quais seriam conservadas no registro. A parte superior dos depósitos que permaneciam acima da superfície de acumulação era susceptível à erosão e mantida em transporte. Posteriormente, duas situaçôes poderiam acontecer: (1) durante um tempo o nível do lençol freático ficava relativamente estático e as fácies da base das dunas eólicas ficavam invadindo as superfícies de interdunas, ou (2) o lençol freático subia de forma gradual enquanto as dunas estavam migrando e cavalgando, de tal maneira que as fácies da base das dunas ficaram interdigitadas com as fácies de interdunas no mesmo nível estratigráfico, mostrando contemporaneidade entre o avanço das formas de leito com a sedimentaçáo da interduna encharcada (Fig. 6).

Dentro da sucessão sedimentar do Membro Macapá, interpretou-se a ocorrência de uma supersuperfície que separa dois conjuntos de associaçóes de fácies: na base a associação de campos de dunas eólicas com interdunas encharcadas e no topo a associação de playa siliciclástica. Essa supersuperficie está marcada pela ocorrência de fácies arenitos com intraclastos de lamito (Ai), além do contato abrupto entre as associaçóes de fácies.

O topo da sucessão tem predomínio de sedimentação de fácies de playa siliciclástica. Estas características são típicas de sistemas com baixo aporte sedimentar que apresentam dunas pequenas e espacialmente isoladas no meio de planícies de interduna com estruturas de adesão, decantação de lama e localmente precipitação de evaporitos. Este sistema também sugere longos períodos onde o lençol freático fica estável, ao mesmo tempo em que pode ocorrer migração de dunas sem cavalgamento. Entre estes episódios ocorrem breves intervalos onde o nível do lençol freático sobe devagar, aumentando o espaço de acomodação e possibilitando o registro estratigráfico de extensos depósitos de interdunas com delgadas e raras intercalações de dunas eólicas. Um resumo da interpretação paleoambiental do Membro Macapa foi desenhado na Fig. 10.

Os fatores que controlam a construção de um erg são: o aporte sedimentar (sediment supply), que é o volume de sedimento gerado por unidade de tempo, e que seja de um tamanho de grão que o vento possa transportar; a disponibilidade sedimentar (sediment availability); e a capacidade de transporte (transport capacity), que é a quantidade de sedimento que pode ser transportada pelo vento (Kocurek
\& Lancaster 1999, Mountney \& Jagger 2004, Mountney 2006). Em geral, a diferença crucial das sequências sedimentares discutidas da Formação Mosquito é a quantidade de disponibilidade sedimentar, que é definida por Kocurek e Lancaster (1999) como a susceptibilidade dos grãos da superfície a serem arrastados pelo vento. A disponibilidade sedimentar é afetada por fatores estabilizadores. No caso da Formação Mosquito estes fatores são os derrames de basaltos e a umidade gerada pelo nível do lençol freático. Por outro lado, o nível relativo do lençol freático é função do nível absoluto do lençol freático que responde principalmente à precipitação e às mudanças climáticas; e da subsidência (Kocurek \& Havholm 1993). Acredita-se, pelo fato de se observar certa ciclicidade dentro das sequências do Membro Macapá (Fig. 4A), que a mudança do nível relativo do lençol freático evidenciada pelas diferenças faciológicas dentro da sucessão é produto principalmente de mudanças climáticas. Embora não se descarte que em menor proporção, períodos de subsidência e soerguimento tenham influência tanto no nível relativo do lençol freático por subsidência, quanto na disponibilidade de sedimentos, por maior erosão durante soerguimentos.

\section{CONCLUSÕES}

As unidades interderrames (intertraps) da Formação Mosquito na Província Parnaíba, a exceção do Membro Macapá, a sul de Fortaleza dos Nogueiras - MA, são depósitos sedimentares isolados entre os diversos fluxos de lavas basálticas de idade ca. $200 \mathrm{Ma}$. Os contatos entre os corpos sedimentares e os derrames basálticos são erosivos na base. Estes depósitos foram depositados em um ambiente continental árido e quente. Em áreas abatidas e segundo disponibilidade sedimentar apresentaram-se duas situações predominantes: 1) as áreas foram inundadas por lagos rasos, com disponibilidade sedimentar mais restrita e com a variação do nível do lençol freático próximo da superfície; ou 2) a disponibilidade sedimentar era suficiente para gerar migração de dunas eólicas.

No pacote sedimentar interderrame, denominado Membro Macapá, foram identificadas duas sequências deposicionais com três associaçôes de fácies principais: lençóis de areia com canais fluviais efêmeros, campos de dunas eólicas com interdunas encharcadas e playa siliciclástica. Estas associações de fácies foram fortemente influenciadas pelo comportamento do lençol freático. A sucessão de eventos retrata longos períodos com o lençol freático estável, ao mesmo tempo em que ocorria a migração de dunas com cavalgamento, no caso das associaçôes de dunas eólicas e sem cavalgamento, no caso das 
interdunas úmidas. Estes episódios ocorreram de forma alternada, com breves intervalos com gradativa elevação do nível do lençol freático. A diferença fundamental entre as associaçóes de fácies deposicionais foi atribuída à disponibilidade sedimentar influenciada por eventos climáticos e subordinadamente por eventos tectônicos.

O Membro Tinguí foi depositado num ambiente de margem de playa lake onde ocorreu decantação de finos, com posterior dessecaçáo, evidenciada pela presença de crostas de evaporitos e gretas de dessecação.

\section{AGRADECIMENTOS}

Os autores agradecem à CAPES pela concessão da bolsa de Mestrado para o primeiro autor, a Pró-Reitoria de Pesquisa da USP, através do Núcleo de Apoio a Pesquisa em Geodinâmica de Bacias Sedimentares, pelo auxílio financeiro para a realização dos trabalhos de campo, aos professores Paulo César Fonseca Giannini pela colaboração na petrografia e Giorgio Basilici pelas valiosas sugestóes que ajudaram no aprimoramento deste artigo.

\section{REFERÊNCIAS}

Aguiar G.A. 1971. Revisão geológica da Bacia Paleozoica do Maranhão. In: Anais do XXV Congresso Brasileiro de Geologia, v.3, p. 113-122.

Allen J.R. 1984. Sedimentary structures: their character and physical basis In: Developments in sedimentology 30, $2^{\text {nd }}$ edition, Amsterdam, Elsevier, 663 p.

Almeida F.F.M. 1986. Distribuição regional e relações tectônicas do magmatismo pós-paleozóico no Brasil. Revista Brasileira de Geociências, 16(4):325-349.

Almeida F.F.M., Hasui, Y., Brito Neves B.B., Fuck R.A. 1977. Províncias estruturais brasileiras. In: SBG, Simpósio de Geologia do Nordeste, Atas, v. 8, p. 363-391.

Baksi A.K. \& Archibald D.A. 1997. Mesozoic igneous activity in the Maranhão province, northern Brazil: ${ }^{40} \mathrm{Ar} /{ }^{39} \mathrm{Ar}$ evidence for separate episodes of basaltic magmatism. Earth and Planetary Sciences Letters, 151:139-153.

Briere P.R. 2000. Playa, playa lake, sabkha: Proposed definitions for old terms. Journal of Arid Envioronments, 45:1-7.

Clemmensen L.B. 1988. Aeolian morphology preserved by lava cover, the Precambrian Mussartût Member, Eriksfjord Formation, South Greenland. Bulletin of the Geological Society of Denmark, 37:105-116.

Cunha F.B. \& Carneiro R.G. 1972. Interpretação fotogeologica do centro-oeste da Bacia do Maranhão. In: Anais do XXVI Congresso Brasileiro de Geologia. Belém, v. 3:64-80.

DeCelles P.G., Langford R.P., Schwartz R.K. 1983. Two new methods of paleocurrent determination from trough cross-stratification. Journal of Sedimentary Petrology, 53(2):629-642.

Fodor, R.V., Sial, A.N., Mukasa, S.B., Mckee, E.H. 1990. Petrology, isotope characteristics, and $\mathrm{K}-\mathrm{Ar}$ ages of Maranhão, northern Brazil, Mesozoic basalt province. Contribuitions to Mineralogy and Petrology, 104:555-567.

Fryberger S.G. 1990. Role of water in eolian deposition In: Fryberger S.G., Krystinik L.F., Schenk C.J. (eds.) Modern and ancient eolian deposits: petroleum exploration and production. Denver, The Rocky Mountain Section SEPM (Society for Sedimentary Geology), p. 5-11.

Góes A.M. 1995. A Formação Poti (Carbonífero Inferior) da Bacia do Parnaiba. PhD Thesis, Universidade de São Paulo, São Paulo, 145p.

Góes A.M.O., Travassos W.A.S., Nunes K.C., 1993. Projeto Parnaíba reavaliação da bacia e perspectivas exploratórias. Belém, Petrobrás. v.1 (relatório interno).
Handford R. 2006. Sedimentology and evaporite genesis in a Holocene continental-sabkha playa basin - Bristol Dry Lake, California. Sedimentology, 29:239-253

Herries R.D. 1993. Contrasting styles of fluvial-aeolian interaction at a downwind erg margin: Jurassic Kayenta-Navajo transition, northeastern Arizona, USA In: North C.P. and Prosser J.D. (eds.) Characterization of fluvial and aeolian reservoirs. Geological Society of London, Special Publication 73, p. 199-218.

Hummel G. \& Kocurek G. 1984. Interdune areas of the back-Island dune field, North Padre Island, Texas. Sedimentary Geology, 39:1-26.

Jolly R.J. \& Lonergan L. 2002. Mechanisms and controls of the formation of sand intrusions. Journal of the Geological Society of London, 159:605-617.

Kocurek G. 1981. Significance of interdune deposits and bounding surfaces in aeolian dune sands. Sedimentology, 28:753-780.

Kocurek, G., 1988. First-order and super bounding surfaces in eolian sequences - bounding surfaces revisited. Sedimentary Geology, 56:193-206.

Kocurek G. \& Fielder G. 1982. Adhesion structures. Journal of Sedimentary Petrology, 52:1229-1241.

Kocurek G. \& Havholm K.G. 1993. Eolian sequence stratigraphy, a conceptual framework. In: Weimer P. \& Posamentier H.W. (eds.) Siciliclastic sequence stratigraphy: American Association of Petroleum Geologists, Memoir 58, p. 393-409.

Kocurek G. \& Lancaster, N. 1999. Aeolian system sediment state: theory and Mojave Desert Kelso dune field example. Sedimentology, 46:505-515.

Langford R. \& Chan, M.A. 1988. Flood surfaces and deflation surfaces within the Cutler Formation and Cedar Mesa Sandstone (Permian), southeastern Utah. Geological Society of America Bulletin, 100:1541-1549

Lima E.A.M. \& Leite J.F. 1978. Projeto global dos recursos minerais da Bacia Sedimentar do Parnaíba. Integração geológica e metalogenética. Relatório Final. Etapa 3. Recife, DNPM/CPRM. 16 volumes.

Lima Filho F.P. 1998. As sequências permo-pensilvanianas da Bacia do Parnaíba. PhD Thesis, Universidade de São Paulo, São Paulo, $166 \mathrm{p}$.

Mabesoone J.M. 1977. Paleozoic-Mesozoic deposits of the PiauíMaranhão sinéclise (Brazil). Sedimentary Geology, 19:7-38. 
Marzolli A., Renne P.R., Picirillo E.M., Ernesto M., Bellieni G., Min A. 1999. Extensive 200-million-year-old continental flood basalts of the Central Atlantic Magmatic Province. Science, 284:616-61.

Merle R., Marzoli A., Bertrand H., Reisberg L., Verati C., Zimmermann C., Chiaradia M., Bellieni G., Ernesto M. 2011. ${ }^{40} \mathrm{Ar} /{ }^{39} \mathrm{Ar}$ ages and $\mathrm{Sr}-\mathrm{Nd}-\mathrm{Pb}-\mathrm{Os}$ geochemistry of CAMP tholeiites from Western Maranhao basin (NE Brazil). Lithos, 122:137-151.

Miall A.D. 2000. Principles of sedimentary basin analysis. New York, Springer-Verlag, 3 ed. 616 p.

Milani, E.L. \& Thomaz Filho, A. 2000. Sedimentary Basins of South America In: Cordani U.G., Milani E.J., Thomaz Filho A., Campos D.A. (eds.) Tectonic Evolution of South America. Rio de Janeiro, $31^{\text {st }}$ International Congresso of Geology, p. 389-450.

Mountney N.P. 2006. Eolian Fácies Models. In: Posamentier H.W \& Walker R.G. (eds.) Fácies Models Revisited. SEMP Special Publication, 84, p. 19-83.

Mountney N. P. \& Jagger A. 2004. Stratigraphic evolution of an aeolian erg margin system: the Permian Cedar Mesa Sandstone, SE Utah, USA. Sedimentology, 51:713-743.

Mountney N., Howell J., Flint S., Jerram D. 1999. Climate, sediment supply and tectonics ascontrol on the deposition and preservation of aeolian-fluvial Etjo Sandstone Formation, Namibia. Journal of the Geological Society of London, 156:771-777.

Mountney N.P. \& Thompson D.B. 2002. Stratigraphic evolution and preservation of aeolian dune and damp/wet interdune strata: an example from the Triassic Helsby Sandstone Formation, Cheshire Basin, UK. Sedimentology, 49:805-834.

Nascimento R.S., Gorayeb P.S.S., Oliveira S.C., Rodrigues A. 2010. Caracterização Geológica e Petrográfica dos derrames basálticos da Formação Mosquito na região de Estreito (MA), Bacia do Parnaíba. In: Boletim de Resumos do $12^{\circ}$ Simpósio de Geologia do Sudeste, Nona Friburgo (RJ). Anais do boletim de resumos, CD-ROM.

Northfleet A.A. \& Melo M. 1967. Geologia da região norte de Balsas, Maranhão. Relatório Petrobrás, Renor-DIREX 268.

Pedreira da Silva A.J., Cunha Lopes R., Vasconcelos M., Bahia R.B.C. 2003. Bacias sedimentares Paleozóicas e Meso-Cenozóicas interiores. In: Bizzi L.A., Schobbenhaus C., Vidotti R.M., Gonçalves J.H. (eds.) Geologia, tectônica e recursos minerais do Brasil: Brasilia, CPRM - Serviço Geológico do Brasil, p. 55-85.
Pittman J. \& Folk R. 1971. Length-slow Chalcedony after Sulphate Evaporite Minerals in Sedimentary Rocks. Nature Physical Science, 230:64-65.

Porada H. \& Bouougri E.H. 2007. Wrinkle structures - a critical review. Earth Science Reviews, 81:199-215.

Pulvertaft T.C.R. 1985. Aeolian dune and wet interdune sedimentation in the Middle Proterozoic Dala Sandstone, Sweden. Sedimentary Geology, 44:93-111.

Rezende N.G.A.M. 2002. A zona zeolítica da Formação Corda, Bacia do Parnaíba. MS Dissertation, Instituto de Geociências, Universidade Federal do Pará, Belém, 142 p.

Romero O.A. 2012. Sucessões sedimentares das formações Mosquito e Corda, exemplos de sistemas eólicos úmidos, Província Parnaíba. Dissertação de mestrado, Instituto de Geociências, Universidade de São Paulo, São Paulo, 85 p.

Scherer C.M.S. 2002. Preservation of aeolian genetic units by lava flow in the Lower Cretaceous ofthe Paraná Basin, southern Brazil. Sedimentology, 49:97-116.

Thomaz-Filho A., Mizusaki A.M.P., Antonioli L. 2008. Magmatismo nas bacias sedimentares brasileiras e sua influência na geologia do petróleo. Revista Brasileira de Geociências, 38:128-137.

Thomaz-Filho A., Mizusaki A.M.P., Milani E.J., Cesero P. 2000. Rifting and magmatism associated with the South America and Africa break up. Revista Brasileira de Geociências, 30:17-19.

Vaz P.T., Rezende N. G. A., Filho J. R., Travassos W. A. 2007. Bacia do Parnaíba. In: Boletim de Geociências da Petrobras, cartas estratigráficas. Centro de Pesquisas da Petrobras (ed.) Boletim de Geociências da Petrobras, 15(2):253-263.

Veevers J.J. 2004. Gondwanaland from 650-500 Ma assembly through 320 Ma merger in Pangaea to 185-100 Ma breakup: supercontinental tectonics via stratigraphy and radiometric dating. Earth Science Reviews, 68:1-132.

Walker R.G. 1992. Fácies, fácies models and modern stratigraphic concepts. In: Walker R.G. \& James N.P. (eds.) Fácies Models: response to sea level change. Toronto, Geological Association of Canada, p. 1-14.

Arquivo digital disponível on-line no site www.sbgeo.org.br 